\title{
連想知識メカニズムを用いた挨拶文の自動拡張方法
}

\author{
吉村 枝里子† 土屋 誠司 ${ }^{\dagger, \dagger \dagger}$ \\ 渡部 広一 ${ }^{\dagger}$ 河 岡司 ${ }^{\dagger}$
}

会話において，まず行われるのが挨拶である、コンピュータやロボットにおいても挨 拶を行うことから次へと会話が広がり人間とのコミュニケーションが円滑に行われる. 本研究では会話処理の中でも特に挨摱処理についてのしくみを提案する．挨摱処理は 従来テンプレートを適用するのみであり，あまり研究は行われてない。しかし，単に 用意されたテンプレートだけを用いると応答が画一化され，設計者の作成した文章の みが出現するという問題点がある。会話文の中でも特に挨拶文は設計者の作成した文 章がそのまま使われることが多い，そこで本稿で提案する挨摱処理システムに抄ける 挨拶文は設計者が用意した挨拶知識ベースに存在しない新たな文章も作り出す。人間 は言葉に関する汎用的な知識を覚え，その言葉に関する常識を持った上で会話を行っ ている。これと同じように，挨摱処理に扔いて，汎用知識と常識判断にあたる連想知 識メカニズムを用いる，挨拶知識ベースにこの連想知識メカニズムを組み合わせて検 討することにより，文章を大規模に拡張し，精錬する手法を提案する.

キーワード： 会話処理，連想知識メカニズム，概念ベース，常識判断メカニズム，挨摱処理， 文章拡張

\section{An Automatic Enhancing Method of Greeting Sentences Using Association Knowledge Mechanism}

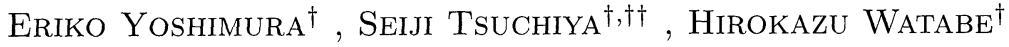 \\ and TSUKasa KAWAOKA ${ }^{\dagger}$
}

When we humans converse with a person, we greet at first. Also in computers or robots, the next subject comes after greeting, and so they communicate with a person smoothly. So far the greeting process was only to apply the template, and its research has not been done so much. However, there is a problem that the responses are uniform by only using a prepared template, and only the sentences made by designer appear. Especially it is often that only the greeting sentences made by designer appear in the conversation. Then, the greeting processing system of this paper produces new greeting sentences. These sentences do not exist in the greeting knowledge base that the designer prepared either. For talking, we humans have general knowledge and common sense of words. In the same way, we use in the greeting process, the association knowledge mechanism that has general knowledge and common sense for computer. The method we proposed in this paper is to expand and refine sentences by combining the association knowledge mechanism with the greeting knowledge base.

KeyWords: Conversational processing, Association knowledge mechanism, Conceptbase, Common sense judgment mechanism, Greeting processing, Sentence extension 


\section{1 はじめに}

近年，ロボットは様々な性能において躍進を遂げてきた。例えば四足で移動するペット用ロ ボット，ダンスを踊るロボット，走るロボット，人の顔を認識しいくつかの命令を受理できるロ ボットなどが挙げられる。それらに共通する未来像は「人と共存する機械」であると言えるだ ろう。人と共存するためには「会話」という大きなコミュニケーション要素が重要となってく ると考えられる。また，ロボットが行う会話には，対人関係を円滑にし，利用者に対する精神 的サポートを行うという目的が挙げられる。

会話において，まず行われるのが挨拶である。挨拶は会話によるコミュニケーションを円滑 にする一端を担っている、コンピュータやロボットに対しても，挨拶を行うことから次に会話 が広がり人間とのコミュニケーションが円滑に行われると考える. 本研究では会話処理の中で も特に挨拶処理についての仕組みを提案する.

挨拶処理は従来テンプレートを適用するのみであり，あまり研究は行われていない. しかし， 単に用意されたテンプレートだけを用いると応答が画一化され，設計者の作成した文章のみが 出現するという問題点がある。挨拶に限らず，対話システムの多くはテンプレートを用いるこ とが多い. 対話システムの一つにEliza(J.Weizenbaum 1965) が挙げられる.このシステムは自 然言語による対話システムであり, 擬人化されたセラピストエージェントによって, カウンセ リングを代行させる．Elizaでは相手の応答に対して答えを評価して返すということはせず，過 去に発言した内容の一部分だけを覚えてその単語を組み込む. また，話題に関しては数種類の パターンを用意している，聞き手としてのシステムである.

また，今日の対話システムに関する研究は，ある一定の夕スク（達成目標）を満たすために 行われる, タスク指向型対話 (堂坂 2001; 神田, 駒谷, 尾形, 奥乃 2004; 杉本, 岩爪, 小林, 岩 下，菅野 2002) に関するものが多くを占めている.これらはテンプレートとその一部に変数と なる予約語を用意しておき，ある条件が満たされるとそれに適当な文章を出力する.

この様にある一定の状況下における制約条件の下，相手の応答に応じたテンプレートを導出 し，テンプレート内の変数を予約語に変換する研究 (堂坂 2001; 神田他 2004; 杉本他 2002) は 多数報告されている。しかし，これらはテンプレートの文章数及び予約語数に依って，出現す る文章数が決定される．会話文の中でも特に挨拶文は設計者の作成した文章がそのまま使われ ることが多い. そこで, 本稿で提案する挨拶処理システムの文章は, 設計者が用意した挨拶知 識べースに存在しない新たな文章も作りだす。このことで多種多様な会話が生み出されると考 えられる。

$\dagger$ 同志社大学大学院工学研究科, Graduate School of Engineering, Doshisha University

†† 三洋電機株式会社研究開発本部ヒューマンエコロジー研究所, Human Ecology Research Center, R\&D H.Q., Sanyo Electric Co,. Ltd. 


\section{2 挨拶処理システムの構成}

「挨拶」とは，日常会話の中において質問の応答や問題の提起を行わない「主張のない会 話」だと定義する。本稿で提案する挨拶処理は相手に対する応答のみならず自ら起こす発話も 対象とする.つまり, 入力变数として現在状態を保持しており, 入力文がある場合はその現在 状態と入力文，ない場合は現在状態のみを入力恋数として挨拶文を作り出す.

本挨拶処理システムでは挨拶として二文を返す。一文目として返答する定型の挨拶を第一会 話文，二文目として話題をふる挨拶を第二会話文とする。この例を図 1 に示す.

\begin{tabular}{|lll|}
\hline 人間 & 「おはようっ」 & \\
システム & 「おはようございます。 & (第一会話文) \\
& 今日はいい天気ですね。」 & (第二会話文) \\
\hline
\end{tabular}

図 1 挨拶処理システムの応答例

挨拶文となる文章として，第一会話文のための定型文と，第二会話文のための可変な文章の テンプレートからなる挨拶知識ベースを作成する。ある程度の基本的なテンプレートの文章知 識を，第 3 節で後述する概念べースと，語種リスト（同義語・類義語・反語リスト），及び常識 判断メカニズムによって大規模に拡張する。また，概念間の関連度を評価する関連度計算 (井 筒, 東村, 渡部, 河岡 2002; 渡部, 河岡 2001) ・シソーラス (池原, 宮崎, 白井, 横尾, 中岩, 小倉，大山，林 1997) ・概念ベース IDF 值 (奥村，渡部，河岡 2005) を用いて精錬する。この ことによって文章は人手によってテンプレートを増やすことなく機械的に大規模に拡張される。

このシステム構成の概要を図 2 に示す.

また，このシステムを使った例として図 3 を示す，入力文「おはよう」に対し，意図理解シ

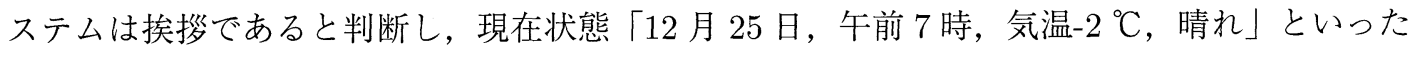
入力からは状態語「クリスマス，朝，冬，寒い，晴れ」を導く。これを用いて定型の挨拶文 (第 一会話文) と話題を続ける挨拶文 (第二会話文) を出力する.

\section{3 連想知識メカニズム}

人間は言葉に関する汎用的な知識を覚え，その言葉に関する常識を持った上で会話を行って いる。これと同じように, 挨拶処理において, 様々な連想知識メカニズムを用いる. 連想知識 メカニズムは大きく, 概念連想メカニズムと常識判断メカニズムにわかれる.これはシステム が持つ汎用的知識と常識にあたるものである。

図 2 に示すように, 概念連想メカニズムはシソーラス, 語種リスト（同義語・類義語・反語 


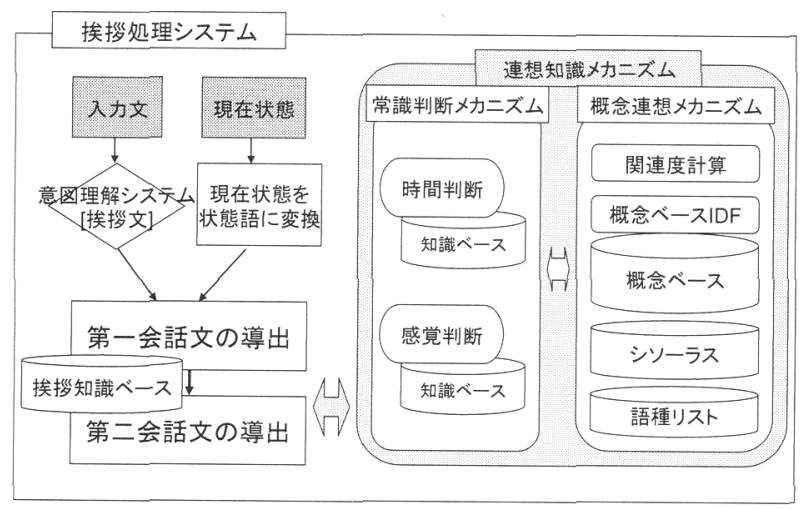

図 2 挨拶処理システムの概略

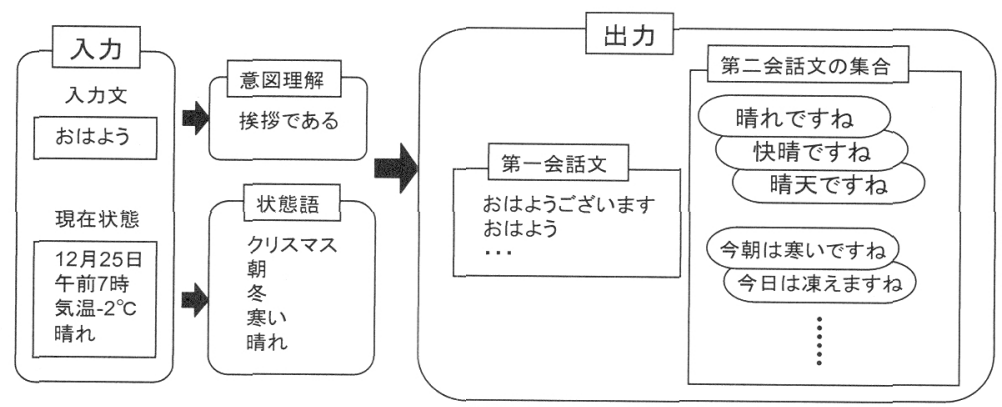

図 3 挨拶処理システム利用例

リスト），概念ベース，それを用いた概念ベース IDF，関連度計算などから成る。概念連想メ カニズムは語と語の関係を沉用的な知識として持つ。また, 常識判断メカニズムは時間判断シ ステム, 感覚判断システム等から成り, 時間や感覚の観点から語を連想, 判断する。本節では これらの連想知識メカニズムについて述べる。

\section{1 概念ベース}

概念ベースにおいて, 任意の概念 $A$ は, 概念の意味特徴を表す属性 $a_{i}$ とこの属性 $a_{i}$ が概念 $A$ を表す上でどれだけ重要かを表す重み $w_{i}$ の対の集合として定義する（式 1）。

$$
A=\left\{\left(a_{1}, w_{1}\right),\left(a_{2}, w_{2}\right), \cdots,\left(a_{n}, w_{n}\right)\right\}
$$

ここで， $a_{i}$ を一次属性と呼ぶ。また便宜上， $A$ を概念表記と呼ぶ。このような属性の定義され た語（概念）を大量に集めたものを概念ベースと呼ぶ。たたし，任意の一次属性は，その概念 
ベース中の概念表記の集合に含まれているものとする，すなわち，属性を表す語もまた概念と して定義されている。したがって，一次属性は必ずある概念表記に一致するので，さらにその 一次属性を抽出することができる。これを二次属性と呼ぶ. 概念ベースにおいて「概念」は $n$ 次までの属性の連鎖集合により定義されている，また，各概念表記に対し平均 30 属性が付与さ れ，属性に付与される重みは，その概念表記に対する重要度であり，各概念表記について，そ の総和が 1.0 となるように正規化されている.

初期の概念ベース（基本 CB）（笠原, 松澤, 石川 1997）は，約 3 万 4 千の概念表記 $A$ とそ の属性 $a_{i}$ 及び重み $w_{i}$ を複数の国語辞書の語義文から自動的に獲得した。これは辞書の見出し 部の単語を概念表記, 語義文に含まれる自立語を属性として抽出し, それらの属性の重みはそ の属性の出現頻度を基に付与する.さらに, 属性の自己参照による新たな属性の追加, 及び不 要な属性の統計的な除去からなる精錬を行うことによって概念ベースを機械構築している.

本論文で用いる概念ベースは基本 $\mathrm{CB}$ (笠原他 1997) に加え, 新聞記事から新たな概念表記 と属性を取得し, 属性の精鍊と適切な重み付け手法を施し, 電子化辞書から抽出した概念を加 えた約 9 万概念を有する概念ベース (奥村他 2005) を用いる.

\section{2 関連度計算方式}

関連度とは，概念と概念の関連の強さを定量的に評価するものである．概念ベースを利用し た概念と概念の間にある関連性を定量的に評価する手法として, ベクトル空間モデルが広く用 いられている。しかし, 本稿では, 概念を定義する属性集合の重みを含めた一致度を基本とした 関連度計算方式を利用し, 概念間の関連性評価を行っている. これは, 関連度計算方式が有限 ベクトル空間によるべクトル空間モデルよりも良好な結果が得られるという報告がなされてい るためである (渡部, 河岡 2001). 本稿では重み比率付き関連度計算方式を使用し, 実験を行う。

任意の概念 $A, B$ について，それぞれ一次属性を $a_{i}, b_{j}$ とし，対応する重みを $u_{i}, v_{j}$ とす る. また，概念 $A, B$ の属性数を $L$ 個, $M$ 個 $(L<M)$ とする.

$$
\begin{gathered}
A=\left\{\left(a_{i}, u_{i}\right) \mid i=1 \sim L\right\} \\
B=\left\{\left(b_{j}, v_{j}\right) \mid j=1 \sim M\right\}
\end{gathered}
$$

このとき, 概念 $A, B$ の重み比率付き一致度 $M a t c h W R(A, B)$ を以下の式で定義する.

$$
\begin{gathered}
\operatorname{MatchWR}(A, B)=\sum_{a_{i}=b_{j}} \min \left(u_{i}, v_{j}\right) \\
\min (\alpha, \beta)=\left\{\begin{array}{cc}
\alpha & (\beta>\alpha) \\
\beta & (\alpha>\beta)
\end{array}\right.
\end{gathered}
$$

このように一致度を定義するのは， $a_{i}=b_{j}$ となる属性に対し，互いの属性の重みの共通部 分が有意に一致すると考えるからである。 
次に属性の少ない方の概念を $A$ とし $(L \leqq M)$, 概念 $A$ の属性を基準とする.

$$
A=\left\{\left(a_{1}, u_{1}\right),\left(a_{2}, u_{2}\right), \cdots,\left(a_{L}, u_{L}\right)\right\}
$$

そして概念 $B$ の属性を, 概念 $A$ の各属性との重み比率付一致度 $\operatorname{Match} W R\left(a_{i}, b_{x i}\right)$ の和が 最大になるように並び替える。

$$
B_{x}=\left\{\left(b_{x 1}, v_{x 1}\right),\left(b_{x 2}, v_{x 2}\right), \ldots,\left(b_{x L}, v_{x L}\right)\right\}
$$

これによって, 概念 $A$ の一次属性と概念 $B$ の一次属性の対応する組を決める. 対応にあふれた 概念 $B$ の属性は無視する（この時点では組み合わせは $L$ 個）。但し，一次属性同士が一致する （概念表記が同じ）ものがある場合 $\left(a_{i}=b_{j}\right)$ は，別扱いにする。これは概念べースには約 9 万 の概念が存在し，属性が一致することは稀であるという考えに基づく．従って，属性の一致の 扱いを別にすることにより，属性が一致した場合を大きく評価する，具体的には，対応する属 性の重み $u_{i}, v_{j}$ の大きさを重みの小さい方にそろえる。このとき，重みの大きい方はその值か ら小さい方の重みを引き，もう一度，他の属性と対応をとることにする．例えば, $a_{i}=b_{j}$ で $u_{i}=v_{j}+\alpha$ とすれば，対応が決定するのは $\left(a_{i}, v_{j}\right)$ と $\left(b_{j}, v_{j}\right)$ であり， $\left(a_{i}, \alpha\right)$ はもう一度他の属 性と対応させる。このように対応を決めて, 対応の取れた属性の組み合わせ数を $T$ 個とする.

重み比率付き関連度とは，重み比率付き一致度を比較する概念の各属性間で算出し，その和 の最大值を求めることで計算する。これを以下の数式により定義する.

$$
\begin{aligned}
\operatorname{Rel}(A, B)=\quad & \sum_{\substack{i=1\\
}}^{T} \operatorname{Match} W R\left(u_{i}, b_{x i}\right) \\
& \times\left(\min \left(u_{i}, v_{x i}\right) / \max \left(u_{i}, v_{x i}\right)\right) / 2
\end{aligned}
$$

以下，重み比率付き関連度を関連度と略し，この関連度 (井筒他 2002 ; 渡部，河岡 2001) を 用いる. 関連度の值は $0 \sim 1$ の連続值をとり，1に近づくほど概念間の関連性が高い. 概念 $A$ と 概念 $B$ に対して関連度計算を行った例を表 1 に挙げる.

表 1 関連度計算の例

\begin{tabular}{clc}
\hline 概念 $A$ & 概念 $B$ & 関連度の值 \\
\hline 花 & 桜 & 0.224 \\
花 & 車 & 0.001 \\
天気 & 晴れ & 0.446 \\
天気 & 学校 & 0.002 \\
\hline
\end{tabular}




\section{3 感覚判断システム}

感覚判断システムとは名詞に対して，人間が常識的に想起でき，特徴付けられる感覚に関す る語を取得するシステムである(渡部, 堀口, 河岡 2004)。この「感覚」とは五感（視覚・聴覚・ 嗅覚・味覚・触覚) の刺激によって得られる感覚を指す。以降, 全ての形容詞, 形容動詞から五 感に関するものを人手で抽出した 98 語を感覚語と呼ぶ。感覚判断システムは名詞とその特徴で ある「感覚」の関係を日常的な名詞の知識ベース (感覚判断知識ベース) 在構築することによっ て明確にし, 必要な感覚語を取得する。感覚判断知識ベースはシソーラス構造をとる。感覚に 関する語という観点で見な場合，名詞にはその名詞のグループが持つ感覚とその名詞固有の感 覚の 2 種類がある。感覚判断知識ベースはこの 2 種類の感覚を継承できるようにするためにシ ソーラスのリーフとノードの関係を用いて構築されている。具体的には, 日常よく使用される 680 語をシソーラスのリーフ (代表語) として登録し, それぞれにその語固有の感覚を付与し ている。また，それらをグループ化しシソーラス構造をとるための語をノード（分類語）とし て 153 語登録し，そのグループが持つ感覚を付与している。この感覚判断知識ベースのイメー 沫図を図 4 に示守。

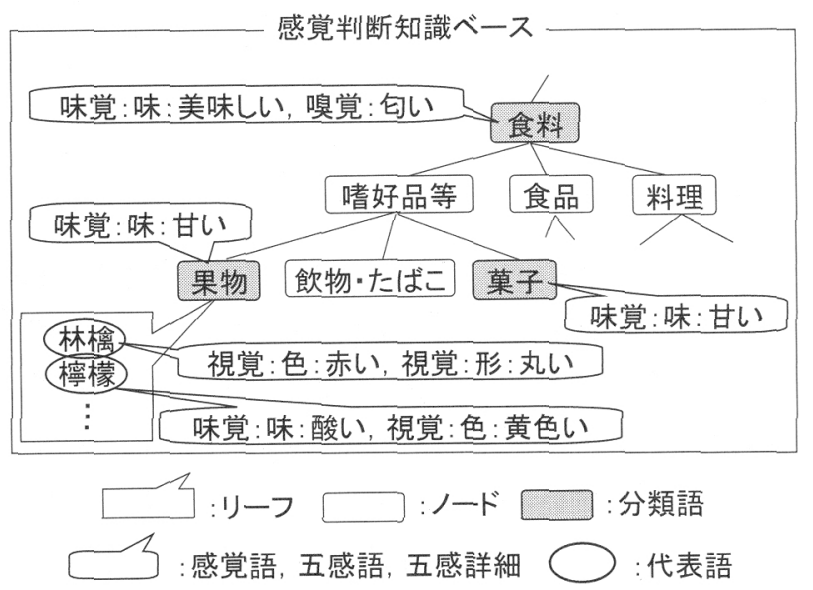

図 4 感覚判断知識ベースのイメージ図

また汎用知識である概念ベースとシソーラスを用いることで，構築した感覚判断知識ベー スにない語 (未知語) に対しても「感覚」を想起することができる。未知語に対して感覚を付与 する場合，分類語としての感覚とその未知語固有の感覚を付与する処理を行う。これは未知語 に対して，関連度計算を用いて感覚判断知識ベース内に含まれる高い関連度を持つ代表語を取 得し，その語群の属するシソーラスのノードから分類語としての感覚を取得する。また，概念 
ベースを用い, 未知語の一次属性に現れる感覚語を, 概念ベースの特徴を利用した自動精鍊法 (詳細は文献 (渡部他 2004) を参照されたい) を行った後, 未知語固有の感覚として取得する. 表 2 に未知語固有の感覚取得の例を示す。表 2 の未知語「パンダ」の例では，その属性から「白・ 黒・大きい」などを未知語固有の感覚として取得することができる.

表 2 未知語固有の感覚取得の例

\begin{tabular}{|c|c|}
\hline 概念 & 属性 \\
\hline パンダ & $\begin{array}{l}\text { 熊, 動物, 白, ライオン, 自然, 生きる, チベット, } \\
\text { ぬいぐるみ，足，黒，山，中国，大きい，林，竹，… }\end{array}$ \\
\hline
\end{tabular}

感覚判断システムを用いた例を表 3 に示す.

表 3 感覚判断システムの使用例

\begin{tabular}{c|c}
\hline 概念 & 感覚語 \\
\hline 林樆 & 赤い, 甘い, 丸い \\
夕焼け & 眩しい, 赤い, 美しい \\
騒音 & 煩い \\
\hline
\end{tabular}

\section{4 時間判断システム}

時間判断システムとは時間を表す言葉（時語）の知識ベース (時間判断知識ベース) を用い て名詞から季節や時刻などの時間を判断するシステム (小畑, 渡部, 河岡 2001 ; 野村, 渡部, 河 岡 2003)である。また時間判断知識ベースにない時語 (未知語) に対しても, 汎用知識である概 念ベースを利用して補完する。時間判断知識ベースにおいて時語は大きく明示的時語と暗示的 時語の二種類に分類される．明示的時語とは「クリスマス」のように明らかな時間を指す語で あり，暗示的時語とは「スキー」のように暗黙に時間を連想する言葉である．前者に関して 156 語, 後者に関しては 187 語格納されている. 特に明示的時語の中で基本的な「春, 夏, 秋, 冬, 梅雨, 朝, 昼, 夕方, 夜」を代表語とし, 全ての格納された時語に対し代表語を付加する. こ のシステムの使用例を表 4 に示す.

\section{4 挨拶処理システムのための知識ベース}

挨拶処理システムは最初に入力として，入力文と現在状態を取得する. 現在状態は年・月・ 日・時間・温度・天候を取得する。現在状態のうち, 時間についてはコンピュータの内部時計を 
表 4 時間判断システムの使用例

\begin{tabular}{c|clc}
\hline 概念 & 時語 & 開始時間 & 終了時間 \\
\hline 桜 & 春 & 3 月 & 5 月 \\
西瓜 & 夏 & 6 月 & 9 月 \\
夕焼け & 夕方 & 16 時 & 18 時 \\
\hline
\end{tabular}

利用し，天候と気温に関しては数時間毎にWEBより取得する.

入力文が意図理解システムによって挨拶と判断された場合及び空欄の場合，挨拶処理システ ムに応答処理を渡す．挨拶処理システムはこれに対し，二文を応答として生成する。一文目は 会話の導入部となる定型の挨拶文, 二文目は以降の会話展開への話題提供のための挨拶文であ る.この二文目はテンプレートではなく，それを元に大規模に拡張された文である．以降，一 文目を第一会話文，二文目を第二会話文とする，そこで，挨拶のための知識ベースとして，第 一会話文知識ベースと第二会話文知識ベースを整理・構築した。本節では挨拶処理システムで 利用するために構築された挨拶知識ベースについて述べる。

\section{1 第一会話文知識ベース}

第一会話文知識ベースは状態語・挨拶入力文に対する定型の応答文を格納した．作成にあ たっては，挨拶であると考える語とその状態を 5 名のアンケートによって調査した．状態語と は現在状態から連想・取得されうる「朝」「寒い」などの単語群である。これにより挨拶である 文章 (入力文), 及び状態語の双方から定型応答語を取得することができる. 状態語・入力文 を応答語に対するグループに分け，グループIDを付与した. そのグループID はそれぞれ応答 語のグループID に対応する．以下にその一部を示す．状態語とそのグループ ID の格納数は 25 語（表 5)，入力文とそのグループ ID のテーブルには 182 語（表 6)，それらに対するグループ ID と応答語を格納したテーブルには 46 語（表 7）を格納した。 その一部を以下に示す.

表 5 状態語テーブルの一部

\begin{tabular}{cl}
\hline 状態語 & グループ ID \\
\hline 時間：朝 & 0001 \\
時間：昼 & 0002 \\
イベント:正月 & 0010 \\
\hline
\end{tabular}

表 6 入力文テーブルの一部

\begin{tabular}{cl}
\hline 入力文 & グループ ID \\
\hline おはよう & 0001 \\
おはよ & 0001 \\
こんにちは & 0002 \\
あけましておめでとう & 0010 \\
\hline
\end{tabular}


表 7 応答語テーブルの一部

\begin{tabular}{cl}
\hline グループID & 応答語 \\
\hline 0001 & おはようございます \\
0002 & こんにちは \\
0010 & あけましておめでとうございます
\end{tabular}

\section{2 第二会話文知識ベース}

第二会話文知識ベースは話題を広げる可変な応答文のテンプレートを格納している。テンプ レートを要素語・修飾語・程度修飾語・限定修飾語に分割し，同じ修飾語に繋がる単語群をグ ループ化した。全単語で 92 語格納し，この単語群から生成されるテンプレートは 803 文とな る.「要素語」は拡張される基本単語となる。「要素語」はグループID とテーマを伴う。テーマ は要素語のシソーラス (池原他 1997) の上位ノードのうち, 要素語のグループを特徵付けられ るノードを選んだものである。このテーマにより，そのテンプレートの話題を大別することが 可能である.このテーブルには 54 語を格納した。この例を表 8 に示す.「修飾語」は要素語を直 接修飾する語群,「程度修飾語」はその程度を強調する語群, 「限定修飾語」は限定された現在の 時間・空間を指し示す語群である。これらにはそれぞれグループ化するための ID がある。修 飾語テーブル（表 9）は 24 語，程度修飾語テーブル（表 10）は 8 語，限定修飾語テーブル（表 11）は 6 語それぞれ格納している。また，これらのグループIDを連結させて文章化するための ルールもまた格納した。 この連結ルールは 30 ルール格納し，この一部を表 12 に示す.

表 8 要素知識テーブルの一部

\begin{tabular}{clc}
\hline 要素語 & グループID & テーマ \\
\hline 天気 & $\mathrm{Y} 0001$ & 気象 \\
晴れ & $\mathrm{Y} 0001$ & 気象 \\
雷 & $\mathrm{Y} 0002$ & 気象 \\
嵐 & $\mathrm{Y} 0002$ & 気象 \\
朝 & $\mathrm{Y} 0003$ & 時間 \\
夕暮れ & $\mathrm{Y} 0003$ & 時間 \\
\hline
\end{tabular}

表 10 程度修飾語テーブルの一部

\begin{tabular}{cl}
\hline 程度修飾語 & グループ ID \\
\hline かなり & $\mathrm{T} 0001$ \\
本当に & $\mathrm{T} 0001$ \\
とても & $\mathrm{T} 0001$ \\
\hline
\end{tabular}

表 9 修飾語テーブルの一部

\begin{tabular}{cl}
\hline 修飾語 & グループID \\
\hline いい & S0001 \\
穏やかな & S0001 \\
激しい & S0005 \\
凄い & S0005 \\
暑い & S0011 \\
涼しい & S0011 \\
\hline
\end{tabular}

表 11 限定修飾語テーブルの一部

\begin{tabular}{cl}
\hline 限定修飾語 & グループ ID \\
\hline 今朝は & G0001 \\
今夜は & G0002 \\
\hline
\end{tabular}

要素知識テーブル，修飾語テーブル，程度修飾語テーブル，限定修飾語テーブルを連結ルー 
表 12 連結ルールの一部

\begin{tabular}{cl}
\hline グループID & 上位連結 ID \\
\hline Y0001 & $\mathrm{S} 0001 / \mathrm{T} 0001 / \mathrm{G} 0000$ \\
$\mathrm{Y} 0002$ & $\mathrm{~S} 0005 / \mathrm{T} 0001 / \mathrm{G} 0000$ \\
$\mathrm{Y} 0003$ & $\mathrm{~S} 0011$ \\
$\mathrm{~S} 0001$ & $\mathrm{~T} 0001 / \mathrm{G} 0000$ \\
$\mathrm{~S} 0005$ & $\mathrm{~T} 0001 / \mathrm{G} 0000$ \\
$\mathrm{~S} 0011$ & $\mathrm{~T} 0001 / \mathrm{G} 0000$ \\
\hline
\end{tabular}

ルを用いて結合させる。この第二会話文知識ベースのイメージ図を図 5 に示す。それぞれの語 はグループ化され，要素語にはテーマを付加している。また，連結ルールによって各々の語は つながり，テンプレートとなる。

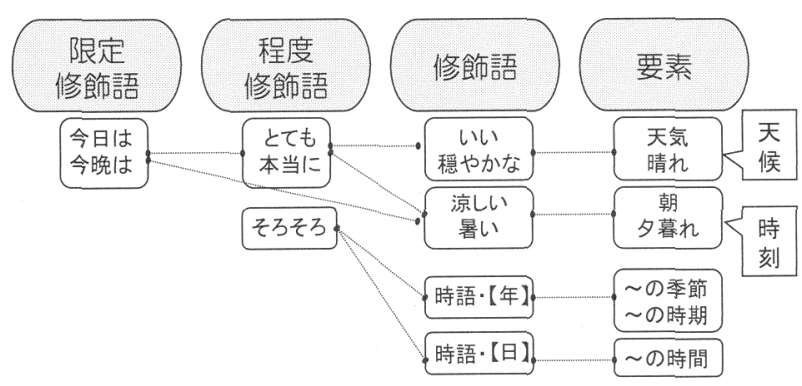

図 5 第二会話文知識ベースイメージ

\section{5 挨拶文の生成}

本節では挨拶処理システムの仕組みについて述べる。挨拶処理システムはまず入力文と現在 状態を取得する。

入力文が存在する場合は入力文を挨拶知識ベースから参照し，第一会話文を決定する。入力 文が存在しない場合は, 現在状態から情報を取得し, その情報から挨拶知識ベースを参照し, 第一会話文を決定する。その後，第二会話文を第二会話文知識ベースより拡張された文章群を 用いて決定する。第二会話文はテンプレート内に存在する基本単語群（挨拶に関係する語群） を概念ベースの一次属性・関係辞書・常識判断メカニズムによって拡張し, その後, 品詞・シ ソーラス・関連度計算・概念ベース IDF・常識判断メカニズムによって精錬する。この具体的 な手法を第 5.4 節，第 5.5 節で述べる。図 6 に第二会話文拡張方法の概要を示す。 


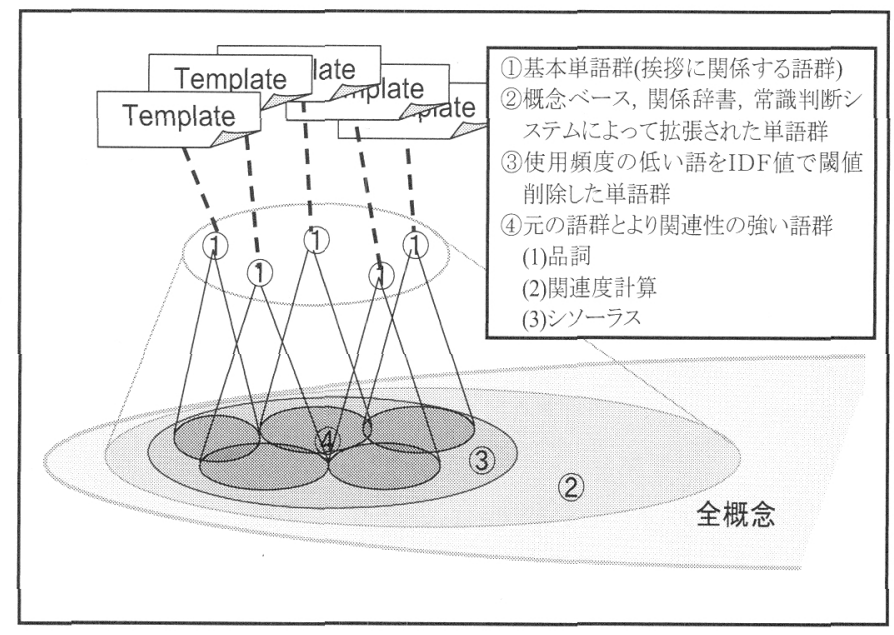

図 6 第二会話文拡張方法の概要

\section{1 意図理解システム}

意図理解システムとは入力文に対する応答方法の違いを区分するため，入力文をそれぞれ 「挨拶」「命令」「疑問」「情報」という意図に分類するシステム (大井，渡部，河岡 2002) であ る。このシステムは意図理解判断のために必要な知識ベースをもつ。 入力文を形態素解析し, この知識ベースを参照することでそれぞれの意図に分類する。この意図理解システムによって 挨拶と判断された文章は挨拶処理，命令文と判断された文章は命令解粕，疑問文と判断された 文章は問題解釈，情報文と判断された文章は応答処理のための意味理解へ処理を渡す。意図理 解システムの概要を図 7 に示す。

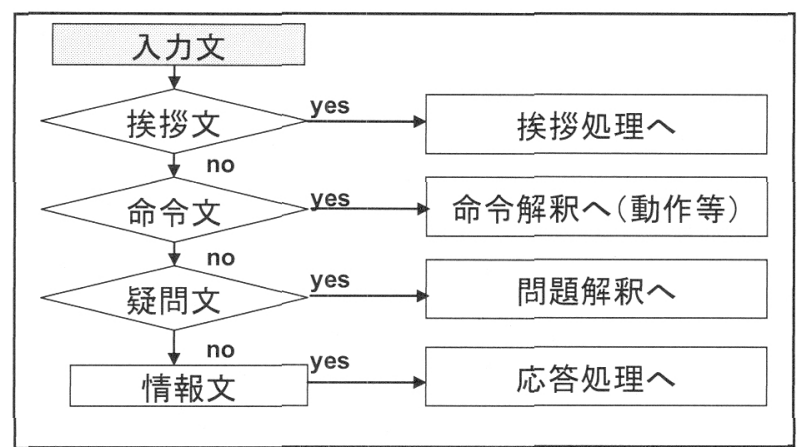

図 7 意図理解システム概要 


\section{2 現在状態からの状態語の取得}

人間は五感から様々な情報を得て，その情報を基に挨拶を行うことが多い.「なんて暑いのだ ろう」「騒がしい」と感じるとその状態を話題に上らせやすい.つまり，思考に上らせやすい状 態が現在状態に存在するとより話題にしやすいと考えられる。この思考に上らせやすい “状態 の単語” ほ以降, 状態語と呼ぶ。この状態語を $A$ として, 現在状態から時間, 気温, 天候に関 する状態語を取得する。天候に関してはその取得した語をそのまま用いるが，数值入力される 時間と気温に関して $A$ を取得する方法を次に示す。

\section{時間}

時間の状態語として年を表す明示的時語，日を表す明示的時語，特定の日を表す明示的時語 を取得する。これらは時間判断システムで利用している時間知識べース内の時語の始点時間と 終点時間を時間軸 (月, 時, 月日) と共に格納した明示的時語知識ベースを参考にして状態語を 取得した，年を表す明示的時語とは春，夏，秋，冬などの季節を表す語である。これは時語知 識べース内の時間軸「月」に類別されている。また，日を表す明示的時語は朝，昼，夕方，夜， 午前，午後などの昼夜を表す語であり，時語知識ベース内では「時」に類別される．特定の日 を表す明示的時語はクリスマス，七夕などの年内イベントを表す語であり，時語知識ベース内 では「月日」に類別される．時語知識ベースの一部を表 13 に示す．現在状態の時間を表す月， 日, 時間と知識べース内の始点時間, 終点時間を比較し, 時間に関する $A_{t i m e}$ を取得し, 取得 した語群を時間軸によって季節，昼夜，イベントに類別して保存する。これを用いることによ り，月日が 12 月 25 日であれば「クリスマス」，月が 6 月から 9 月の間は「夏」といった状態語 を取得することができる。

表 13 時語知識ベースの一部

\begin{tabular}{c|clclc}
\hline 名称 & ふりがな & 時間軸 & 始 & 終 & 属性 \\
\hline クリスマス & くりすます & 月日 & $12 / 25$ & $12 / 25$ & point \\
夏 & なつ & 月 & 6 & 9 & period \\
午後 & ごご & 時 & 12 & 23 & period \\
\hline
\end{tabular}

\section{気温}

気温の平年值を用いて気温に関する $A_{t e m p}$ を求める。平年值とは平均的な気候の状態を表 す指標である，その求め方は世界気象機関（WMO）が定めており，西暦の一位が 1 の年から 数えて連続する 30 年間について累年平均值を算出したものである. 2000 年からは気象庁が作 
成・提供している 1971 年から 2000 年までの平年值が指標となっている. 気温の平年値を $T_{a v e}$, 現在の気温を $T_{n o w}$ とし， $A_{t e m p}$ を以下の図 8 のように定める.

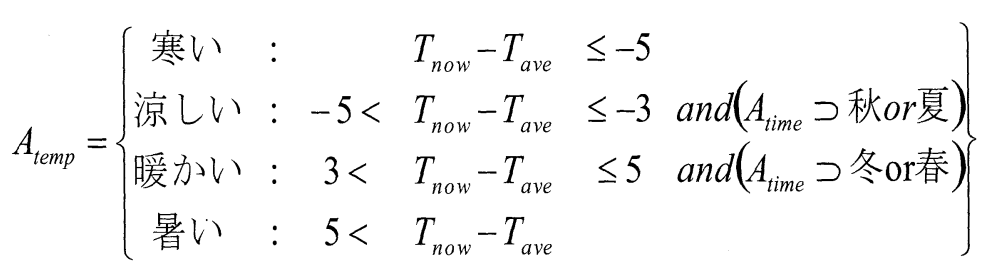

図 8 気温に関する状態語の取得

\section{3 第一会話文の取得}

第一会話文を契機に会話は始まる。この文章は総じて定型の挨拶文であり，以降の会話を円 滑にする導入部の役割を果たす。これを第一会話文知識べース及び入力文, 状態語を用いて取 得する，本稿で提案する会話システムでは相手の応答に限らず，自発的に会話を作成するため， 入力文が存在する場合と存在しない場合がある. 入力文がある場合，これを意図理解システム に渡す，意図理解システムによって「挨拶」と判定された場合，第一会話文知識ベースの入力文 テーブルを参照し, 応答語テーブルから第一会話文を取得する. 入力文が存在しない場合, 現 在状態から状態語を取得する。これを第一会話文知識ベースの状態語テーブルを参照し, 応答 語テーブルから第一会話文を取得する，例えば，現在状態が夜の場合，入力文がないと「こん ばんは」と応答するが，対話者が「おはよう」と入力すれば「おはようございます」と応答す る、相手に合わせた挨拶がコミュニケーションを円滑にする役割を果たすと考えられる。

\section{4 第二会話文の拡張}

第二会話文は話題を提供する挨拶文である。この話題は日常会話の中において質問の応答や 問題の提起を行わない. 話題として多く用いられるのは現在状態から連想される事柄である. 例えば，気象，季節，朝夕，体感温度などが挙げられる。しかし，第二会話文を人手で作成す ると，手間がかかり，設計者が設定した応答しかできない。そこである程度のテンプレートを 用意し，そこから汎用知識ベースを用いて機械自身の手で連想を広げる。

但し，ここでは文章を拡張することが目的であり，最終的には現在状態にマッチングする文 章を応答として返すことを目指しているが，本論文では現在状態を用いて文章を選定する所ま では範囲としない。本章では文章を大規模に拡張し，その文章が挨拶において文章単独として 常識的であるように，文章の精錬を行う。 


\section{状態語からの拡張}

現在状態から取得した状態語のうち，時間に関する状態語から時間判断システムを利用して 連想し，要素語を拡張する．例えば，現在時間が “ 12 月 25 日／午前 7 時”とした例を表 14 に 示す。ここから状態語として “季節／冬”, “昼夜／朝”, “イベント／クリスマス”が取得でき る.この状態語それぞれを時間判断システムによって連想する。冬からは “蟹”，朝からは“出 勤” 等の連想語が派生する。これを要素語として, それぞれのテンプレートの可変部に戻し, “蟹の季節ですね”“出勤の時間ですね”といった文章拡張を行うことができる.

本論文では文章拡張の有効性を調べるため, 現在状態を定めて文章を拡張するのではなく, 全ての状態語を用いてそこから想起できる文章拡張を行った.

表 14 現在時間：12 月 25 日 $/$ 午前 7 時の場合の例

\begin{tabular}{|c|c|c|c|}
\hline & 状態語 & 連想語 & テンプレート \\
\hline 季節 & 冬 & 蟹，暖房，ソリ，炬燵，スキー, ‥ & 〜の季節ですね \\
\hline 昼夜 & 朝 & 出勤, 開店, 覚醒, 鶏鳴, $\cdots$ & 〜の時間ですね \\
\hline イベント & クリスマス & トナカイ, サンタクロース, $\cdots$ & 〜の時期ですね \\
\hline
\end{tabular}

\section{連想による修飾語の拡張}

人は話題の言葉に対して想起した感覚を加えて会話にする．そこで感覚判断システムの連想 によって修飾語を拡張する。ここで用いる要素語は第二会話文知識ベースの要素知識テーブル に存在するものを用いる。これらの要素語に対し, 連結する基本的な修飾語は第二会話文知識 ベースの修飾語テーブルに用意しているが, さらに感覚判断システムによって修飾語を拡張す る.この例を表 15 に示す。まず，要素語を感覚判断システムにかけ，感覚想起を行う．感覚想 起された修飾語が修飾語テーブルになかった場合, その修飾語をその要素語に対する修飾語と して追加・拡張する。

表 15 感覚想起の例

\begin{tabular}{c|c}
\hline 要素語 & 感覚想起 \\
\hline 夕焼け & 眩しい, 赤い, 美しい \\
\hline 春 & 爽やかな, 待ち遠しい, 暖かい \\
\hline
\end{tabular}

連想による要素語の拡張 汎用的な知識ベースである概念ベース及び語種リスト（反対語・同 義語）を用いて要素語の連想を行う。ここで用いる要素語とは, 第二会話文知識ベースの要素 
知識テーブルに存在する要素語 54 語のことである。語種リストは国語辞書等から自動構築され た反対語リスト，同義語リストを持つ. 反対語リストとは反対の意味を持つ語のセットを約 1 万 6000 語登録したデータベースである。同義語リストとは同義の意味を持つ語のセットを約 20 万セット登録したデータベースである.

反対語による拡張 要素語と同系列の単語群を取得するため反対語リストを利用することによっ て拡張する，要素語に対する反対語とそれに対する反対語を取り続けることにより，同系列の 単語群の取得が可能となる．以下のアルゴリズムで反対語による拡張語群 $E$ を取得する.

(1) 要素語 $Y$ の反対語群 $Y_{i}$ を取得する. $Y$ と $Y_{i}$ を語群 $E$ とする.

(2) . 語群 $E$ の全ての反対語群 $E_{i}$ を取得する.

(3) $E_{i}$ と $E$ を比較する. $E_{i}$ の中で $E$ に含まれていない語を $N$ とする.

(4) $N$ が無ければ， $E$ を反対語による拡張語群 $E$ として取得する． $N$ が存在すれば， $E$ に $N$ を加えたものを新たな $E$ として (2)を行う.

同義語・一次属性による拡張 要素語とその反対語による拡張語群 $E$ を, 同義語と概念ベース によってさらに拡張する。以下のアルゴリズムで同義語・一次属性による拡張語群 $E$ を取得 する。

(1) 拡張語群 $E$ の全ての単語の同義語群 $E_{s}$ を取得する.

(2) 拡張語群 $E$ の全ての単語の一次属性 $E_{c}$ を概念ベースより取得する.

(3) 拡張語群 $E$ に $E_{s}$ と $E_{c}$ を加え, 同じ語を削除する.

（4）（3）で取得した語群を同義語・一次属性による拡張語群 $E$ として取得する.

\section{5 精度向上}

会話文が常識的に正しい文章になるように要素語の拡張語群に対し精錬を行う。

\section{品詞による精錬}

拡張語群 $E$ に対し, 品詞による精錬を行う。本来の要素語 $Y$ が収まるようにテンプレート は作られているため, 要素語 $Y$ と品詞が異なるものは収まりにくいからである。よって, 拡張 語群 $E$ 内において要素語 $Y$ と同じ品詞の語を, 品詞による精錬語群 $S_{h}$ として取得する.

\section{シソーラスによる精錬}

品詞による精錬語群 $S_{h}$ に対し，シソーラス (池原他 1997) による精錬を行う．語群 $S_{h}$ 内に は様々な多義語が含まれていることが多い，例えば要素語「山」に対して「山岳」「山鉾」「ク ライマックス」等の多義語が含まれる。これに対し，挨拶文として利用したいものは視界に入 
る自然物としての「山岳」という意味の語群である。このため, シソーラスを用いて自然物と しての意味を持つものだけを取得する。このようにシソーラスによる精錬語群 $S_{t}$ を以下のアル ゴリズムによって実現する。

(1) 要素知識ベースより, 要素語 $Y$ のテーマ語 $\mathrm{T}$ を取得する.

(2) 語群 $S_{h}$ の各単語に対し，シソーラスの全親ノードを取得する.

（3） シソーラスの全親ノードとテーマ語 $T$ を比較し，一致するノードが存在する単語を 取得し，これをシソーラスによる精錬語群 $S_{t}$ とする.

\section{関連度による精錬}

シソーラスによる精錬語群 $S_{t}$ に対し，関連度計算による精錬を行う。これは，テンプレー トの可変部に入れるために人手で用意した適切な語群との関連度を用いる．適切な語群との関 連が高ければ適切だと考えたためである。次のアルゴリズムによって適切な要素語群との関連 度による精錬語群 $S_{r}$ を取得する。

（1）要素語 $Y$ と同じグループ ID を持つ語群 $Y_{g}$ を第二会話文知識ベース内要素知識ベー スより取得する。

(2) 語群 $Y_{g}$ と語群 $Y_{g}$ の全単語間で関連度計算を行う.

(3) (2) の平均值を求める.これを要素語 $Y$ の閾值とする.

(4) 語群 $S_{t}$ の各単語と語群 $Y_{g}$ の関連度計算を行う.

(5) (4)の平均值を求める.

（6）（5）と(3) で求めた閾值を比較し, 閯值以上の単語群を取得する.これを適切な要素 語群との関連度による精錬語群 $S_{r}$ とする。

\section{IDF 值による精錬}

IDF 值は情報検索の分野で用いられる単語重み付け手法であり，稀に出現する語は重要であ るという観点から重み付けされた対数文書頻度である.ここでは以下の方法で概念べース IDF 值を求める.

（1）概念ベース内の属性全てを対象とし，概念連鎖によって三次まで展開する.

（2）全概念数（87242）を $N_{A l l}$ とする。また，全概念を三次まで展開した属性群 (文書空 間) 内での概念 $t$ の出現概念数を $d f(t)$ とし, $i d f(t)$ を以下の式で計算する.

$$
i d f(t)=\log \frac{N_{A l l}}{d f(t)}
$$

関連度による精錬語群 $S_{r}$ に対し，概念べースの IDF 值を用いて精錬を行う．汎用的な辞書 の知識である概念べース内で使用頻度の低い語は日常会話でもあまり使用されない。そこで, IDF 值を用いると，概念べース内で使用頻度の低い語として雑音を除くことができる．本来， 
IDF 值とは出現頻度の低い語の值が大きく, 重要である, という観点で重み付けされるもので あるが，ここでは，「稀に出現する語は一般的でない」という観点で，そのような語を抽出する ための単なる「計算式」として用いる。闇值は実験によって適切な值を求め, IDF 值が閾值以 下の語を語群 $S_{r}$ から抽出し，これを IDFによる精錬語群 $S_{i}$ とする.

実験は閾值を IDF 值 $0.2 \sim 3$ まで 0.2 毎に変化させて取得した精錬語群 $S_{r}$ を用いた。 $S_{r}$ を 文章化し，ランダムに 100 文抽出する。 それを 3 人の目視によって常識的に正しいか否かを評 価した. 100 文に対して常識的に正しいとした割合を算出し, その 3 人の平均值を精度とした. また拡張語から表現できる全文章数をその文章数とする。このときの精度と文章数のグラフを 図 9 に示す。図 9 より IDF 值が小さくなれば精度は上がり, 文章数は減少する。 また, IDF 值 が 0.8〜 1.4の間，あまり精度が変わらないことがわかった，そこで，その間で最も文章数が多 くなるIDF 值 1.4 が閾值として適当であると考えられる。これをIDFによる精錬を行う際に用 いる閾値とした.

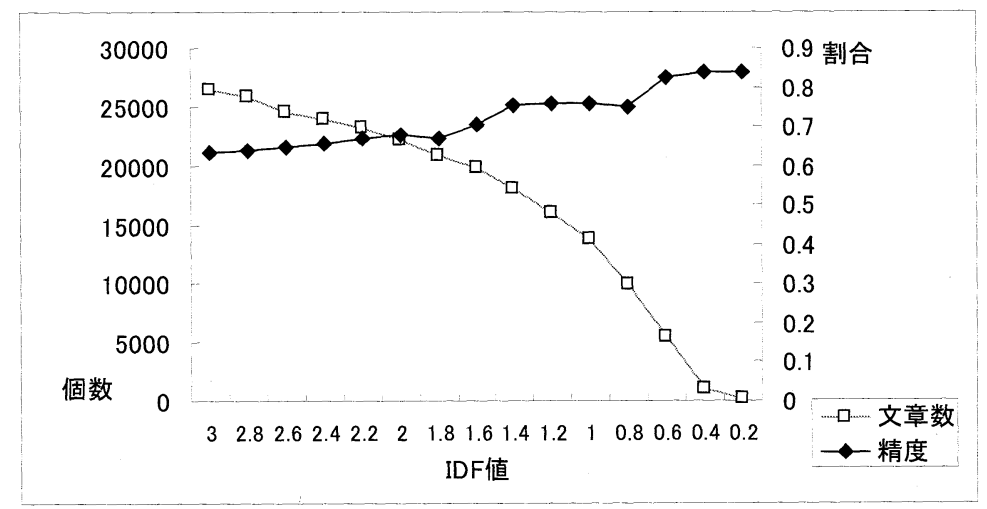

図 9 idf 值の変化に伴う精度と文章数

\section{時間判断システムによる文章の妥当性}

精錬語群 $S_{i}$ から第二会話文知識ベースを用いて文章化する．拡張前の要素語のもつ修飾語 の上位 ID から文章を作成する。このとき，限定修飾語と要素語の状況が全く異なることがある. 例えば「今朝はきれいな夕焼けですね」「今夜は涼しい昼ですね」等である。このような文章は どのような状況であっても正しくない. 時間判断システムを用いてこれらの文章を削除する. 具 体的には，文章化する際に，限定修飾語と拡張要素語の双方を時間判断システムにかける。限 定修飾語「今朝」と要素語「夕焼け」を時間判断システムにかけた場合の例を表 $16 に$ 示す。こ こで時間軸が一致（月日，月，時）し，かつ同じ時語を含まない場合，その文章を削除する。 
表 16 時間判断システム結果の例

\begin{tabular}{|c|c|c|}
\hline & 時間判断結果 (時間軸) & 時間判断結果 (時語) \\
\hline 今朝 & 時 & 今日, 朝 \\
\hline 夕焼け & 時 & 夕方 \\
\hline
\end{tabular}

\section{6 実験結果と考察}

精錬結果と拡張された文章数について調査を行う。調査方法は，以下のとおりである。まず， 精錬語群を文章化し，ランダムに 300 文章抽出する。それを 3 人の目視によって挨拶において文 章単独として常識的に正しいか否かを評価した. 300 文に対して常識的に正しいとした割合を算 出し, その 3 人の平均値を精度とした. また拡張語から表現できる全文章数を文章個数とする.

挨拶において文章単独として常識的である，というのは，あらゆる状況下で第一会話文（お はよう，こんにちは，など）の後に続いて発する可能性のある文章を意味する．元のテンプレー トも関係がないため，実験時には元になったテンプレートは被験者に提示せずに行った．拡張 した文章 300 文のみに対し，文章として非常識でないか，及び挨拶として適当か (状況を限定せ ず，第一会話文の後に続いて発することが妥当か) を判断基準として評価した.

\section{ここまでの実験結果と考察}

第 5.4 節の拡張を行った場合 (拡張のみ), 第 5.5 節の精錬（品詞, シソーラス, 適切な要素 語群との関連度，概念べース IDF，時間判断）を行った場合のそれぞれの精度を図 10 に，文章 個数を対数グラフで表したものを図 11 に示す.

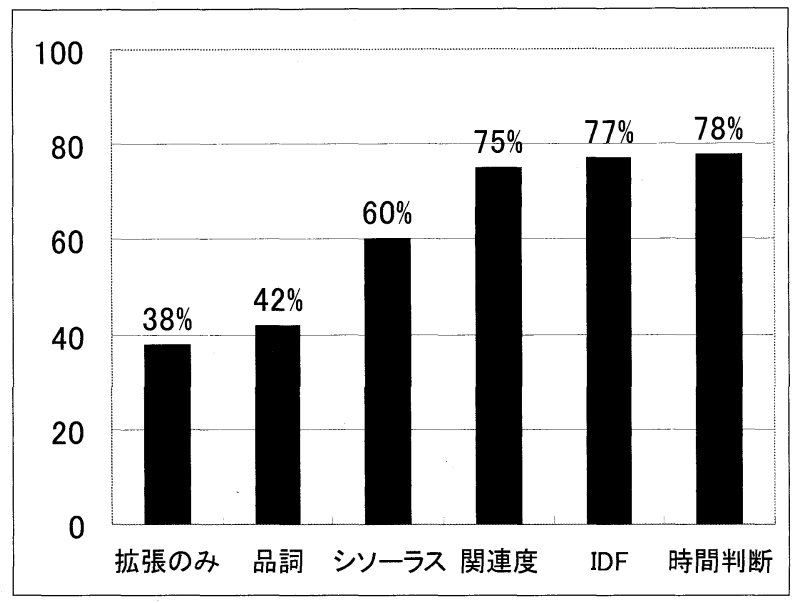

図 10 本手法の精度 


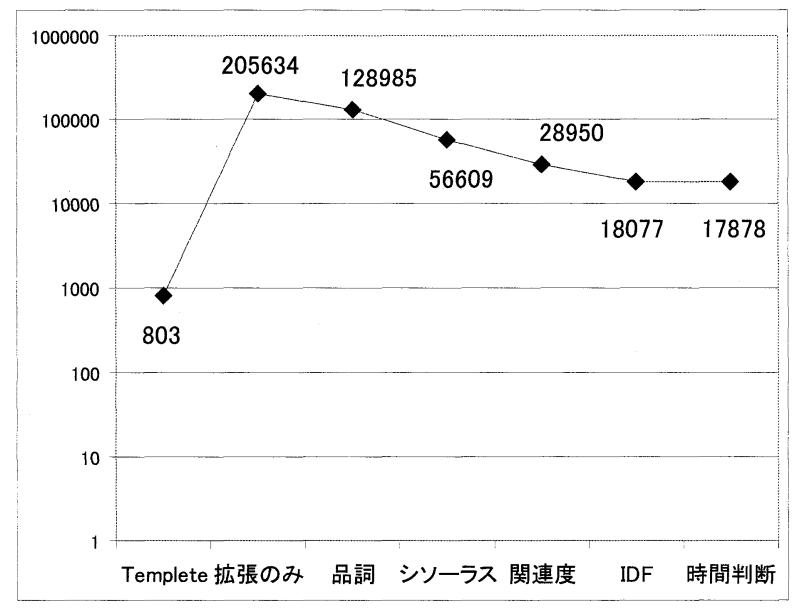

図 11 本手法の文章数

拡張のみの精度は $38 \%$ と非常に低かったにもかかわらず，精錬を経て，78\%に精度向上し た.また，最初のテンプレート数が 803 文であったのに対し，拡張と精錬によって 17878 文が 自動拡張された。ここで不適切とされた例には，次の図 12 のようなものがあった。

暖かい熱帯夜ですね

今日はとても穏やかな荒波ですね

とてもうっとうしい晴れ間ですね

図 12 不適切な文章例

これらは修飾語と要素語が意味として連結しない形をとっている。このため, 修飾語と要素 語との関係を加味する必要があると考えられる。

\section{新たな関連度計算の提案}

上記実験結果から，修飾語と要素語との関係性を加えることの必要性が感じられたため, 関 連度を用いることにより，その関係性を追加する．次のアルゴリズムによってこれを実現する。 （1）作成された文章の修飾語と同じグループ内 (第二会話文知識ベースより) の語の一次 属性を取得

(2) 要素語と (1)の語の関連度計算を行い, 平均值を求める

(3)＼cjkstart要素語が含まれるグループ全てに (2)を行い, 最低平均值を導出 
(4)（3）をその要素語グループの閾値とする

(5) 拡張した単語と (1) の語の関連度計算を行い, 平均值を求める

(6) (5) が (4)の閾值以下なら削除する

（7）これを, 修飾語の属性との関係を加味した関連度による精錬語群とする

テンプレート「うっとうしい雨ですね」を用いた際の例を図 13 に示す．まず，修飾語「うっ とうしい」と同グループに属する「うっとうしい，嫌な」の一次属性を取得する。これとテンプ レートの要素語「雨」と同グループに属する「天気, 曇り, 雨」との関連度の平均值を計算す る.「天気，曇り，雨」は人間によって修飾語との関連があると判断されたものなので，ここで 最も低い值を出した関連度を必要最低限の值と考え, 䦐値とする.図 13 の場合は「雨」との関 連度 0.1136 が最も低いため，これが間值となる.「雨」から拡張された語群と「うっとうしい, 嫌な」の一次属性との関連度の平均值がこの閾值よりも低い場合, これを削除する.図 13 の場 合は「快晴」と「晴れ間」が除去される。このことにより，少なくとも修飾語との関連がないと 考えられる語を除くことができる。ここで, 第 5.5 節で行った“適切な要素語群との関連度に

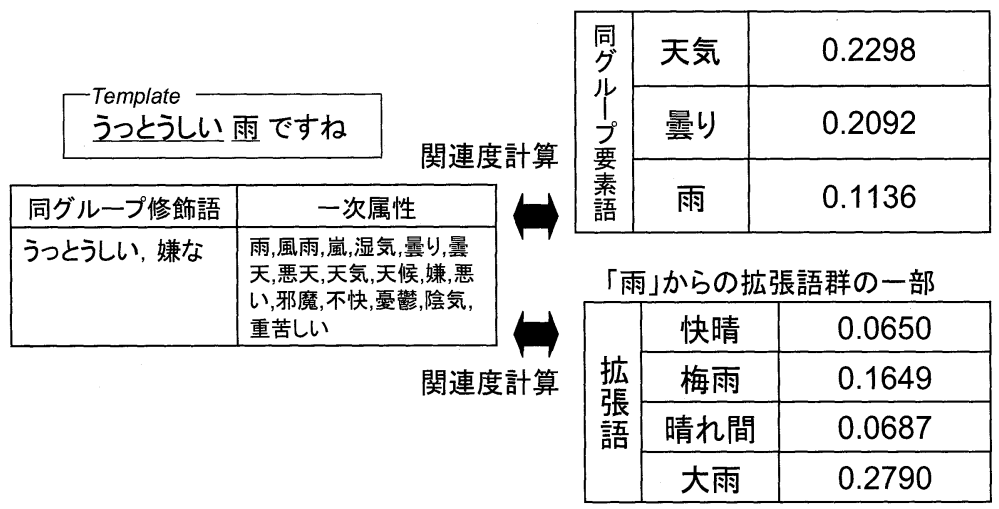

図 13 修飾語の属性との関係を加味した関連度による精錬方法の例

よる精錬手法”と “修飾語の属性との関係を加味した関連度による精錬手法”を入れ替えて, 精 度と文章個数を求めた。 これを図 14 に示す. 前者の手法を使ったものを関連度 1 , 後者の手法 を使ったものを関連度 2 とする。すると関連度 1 を使った手法の精度は $77 \%$, 関連度 2 を使っ た手法の精度は $84 \%$ となり，関連度 2 の手法を用いた方が $7 \%$ の向上が見られた。また，全文 章個数も約 18000 個から約 24000 個に増加することがわかり, “修飾語の属性との関係を加味 した関連度による精錬手法”の方がより有効であった。 次に, “適切な要素語群との関連度に よる精錬手法”と “修飾語の属性との関係を加味した関連度による精錬手法”の双方を行った 場合の精度と文章個数を求めた。これを図 15 に示す。順序を入れ替えても, “修飾語の属性と 


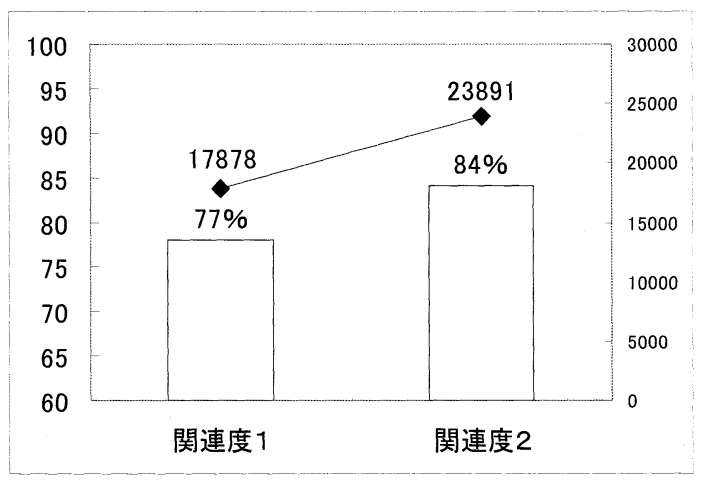

図 14 関連度 1（旧手法）と関連度 2（新手法）の精度と文章個数

の関係を加味した関連度による精錬手法”だけの場合と比較して大きな差異はなく，文章個数 のみが大きく減少した。このため，両方を行うのではなく，関連度による精錬を“修飾語の属 性との関係を加味した関連度による精錬手法”にすることが適切であると考えられる．この手

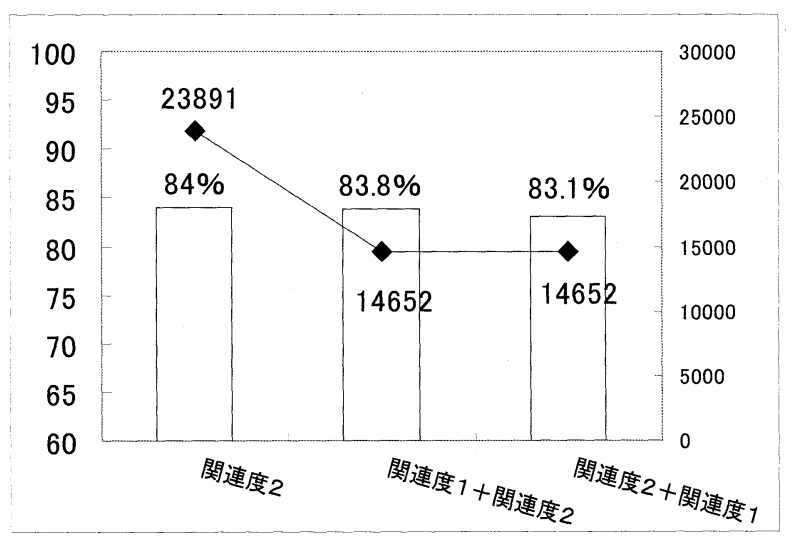

図 15 関連度 1 と関連度 2 の両方を用いた場合の精度と文章個数

法によってある一文のテンプレートから拡張された文章の例を表 17 に示す.

表 17 に示した例において,「精錬文章群」が「テンプレート」に対し本提案手法を用いたシ ステム出力例である。また，評価実験において，評価者全員が常識的であると判断した文章例 を○，常識的ではないと判断した文章例を×として示す． 5.4 節「第二会話文の拡張」において， テンプレートを拡張した当初は「精錬文章群」と「削除された文章群」の両方が混在している. 
これに対し，5.5節で提案した精度向上方法を用いることで，文章は精錬される．このときに削 除された文章の例を「削除された文章群」に記載する，例えば「きれいな川ですね」というテ ンプレートに対し, 様々な文章 (拡張文章群) が生成される.しかし, 提案手法によって, 常 識的でない（非常識な）文章が大きく削除された。挨拶として (第一会話文に続く文章として) 「きれいな流れですね」「きれいな景観ですね」という文章はある状況下で可能であるのに対し， 「きれいな河童ですね」「きれいな濁流ですね」といった文章は非常識である。このような文章 を自動的に削除することで拡張文章群を精錬し，本提案の有効性を示すことができた.

表 17 一文から拡張した文章例

\begin{tabular}{|c|c|c|c|c|}
\hline \multirow{2}{*}{ テンプレート } & \multicolumn{4}{|c|}{ 拡張文章群 } \\
\hline & \multicolumn{2}{|l|}{ 精錬文章群 } & \multicolumn{2}{|l|}{ 削除された文章群 } \\
\hline \multirow{5}{*}{ きれいな川ですね } & きれいな流れですね & O & きれいな河童ですね & $x$ \\
\hline & きれいな景観ですね & 0 & きれいな背水の陣ですね & $x$ \\
\hline & きれいな清流ですね & O & きれいな濁流ですね & $x$ \\
\hline & きれいな山水ですね & O & きれいな犯罪事件ですね & $x$ \\
\hline & きれいな風光ですね & O & きれいな小川ですね & $\bigcirc$ \\
\hline \multirow{5}{*}{ 夕焼けですね } & 美しい夕焼けですね & 0 & 電磁波ですね & $x$ \\
\hline & 赤い夕日ですね & 0 & 空虚ですね & $x$ \\
\hline & 空模様ですね & $x$ & 赤色ですね & $x$ \\
\hline & 日没ですね & O & 沈没ですね & $x$ \\
\hline & 光ですね & $x$ & 夕映えですね & O \\
\hline
\end{tabular}

\section{6 おわりに}

本稿では，日常会話の中において質問の応答や問題の提起を行わない「主張のない会話」で ある「挨拶」の処理手法を構築した。また, 話題の展開に繋がる第二会話文をテンプレートだ けではなく, 汎用知識ベースである概念ベースや常識判断メカニズムを用いて文章拡張し, 品 詞，シソーラス，関連度計算，概念ベース IDF，時間判断システムによって精錬する手法を考 案し，その有効性を実験によって検証した。

また，第 5.6 節までの操作を行うことによってテンプレートは自動的に大きく拡張・精鍊さ れた。この文章群を用いて現在状態に即した第二会話文を取得することが次の課題となる。こ の挨拶処理手法を用いることにより，少数のテンプレートを連想により拡張し，挨拶を膨大な 文章から選択することが可能となる。このことで，単調となりがちなテンプレートの会話に効 果をもたらすと期待される.

謝辞 本研究は文部科学省からの補助を受けた同志社大学の学術フロンティア研究プロジエ クトにおける研究の一環として行った. 


\section{参考文献}

堂坂浩二 (2001). “夕スク指向型対話における漸次的発話生成モデル.” 情報処理学会論文誌, $\mathbf{3 7}$ (12), pp. 2190-2200.

井筒大志，東村貴裕，渡部広一，河岡司 (2002). “概念ベースを用いた関連度計算方式の精度評

価.”信学技報, NCL2001-94, pp. 117-122.

池原悟, 宮崎正弘, 白井諭, 横尾昭男, 中岩浩巳, 小倉健太郎, 大山芳史, 林良彦（編） (1997).

日本語語彙体系. 岩波書店.

J.Weizenbaum (1965). "ELIZA - A Computer Program For the Study of Natural Language

Communication Between Man and Machine." Communications of the Association For Computing Machinery, 9 (1), pp. 36-45.

神田直之，駒谷和範，尾形哲也，奥乃博 (2004). “データベース検索音声対話システムにおける

履歴を考慮した検索条件の管理.” In FIT2004, pp. LG-001, 131-132.

笠原要，松澤和光，石川勉 (1997). “国語辞書を利用した日常語の類似性判別.”情報処理学会

論文誌, 38 (7), pp. 1272-1283.

小畑陽一，渡部広一，河岡司 (2001). “短文の名詞と動詞から時間/季節を判断するメカニズム。”

信学技報, AI2000-56, pp. 1-6.

野村理樹, 渡部広一, 河岡司 (2003). “時間の常識的判断システムにおける未知語処理方式の検

討.”情報科学技術フォーラム 2003, E-047, pp. 191-193.

奥村紀之, 渡部広一, 河岡司 (2005). “電子化新聞を用いた概念べースの拡張と属性重み付与方

式.”情報処理学会研究報告, 2005-NL-166, pp. 55-62.

大井健治, 渡部広一, 河岡司 (2002). “知能ロボットの意図理解と応答制御方式.”言語処理学

会第 8 回年次大会発表論文集, A2-9, pp. 275-278.

杉本徹, 岩爪道昭, 小林一郎, 岩下志乃, 菅野道夫 (2002). “秘書エージェントのための対話管

理とその適応機能.”人工知能学会第 16 回全国大会, 2B3-02, pp. 131-132.

渡部広一，河岡司 (2001). “常識的判断のための概念間の関連度評価モデル.” 自然言語処理, 8 (2), pp. 39-54.

渡部広一, 堀口敦史, 河岡司 (2004). “常識的感覚判断システムにおける名詞からの感覚想起手

法.” 人工知能学会論文誌, $19(2)$, pp. 73-82.

\section{略歴}

吉村 枝里子: 2004 年同志社大学工学部知識工学科卒業. 同大学院工学研究科 知識工学専攻博士前期課程在学. 知識情報処理の研究に従事.

土屋 誠司: 2000 年同志社大学工学部知識工学科卒業. 2002 年同大学院工学研 究科知識工学専攻博士前期課程修了. 同年, 三洋電機株式会社入社. 2004 年 
同志社大学大学院工学研究科知識工学専攻博士後期課程入学. 主に, 常識的 判断システムの研究に従事. 言語処理学会, 人工知能学会, 情報処理学会, 電子情報通信学会各会員.

渡部 広一: 1983 年北海道大学工学部精密工学科卒業. 1985 年同大学院工学研 究科情報工学専攻修士課程修了. 1987 年同精密工学専攻博士後期課程中途退 学. 同年, 京都大学工学部助手. 1994 年同志社大学工学部専任講師. 1998 年同助教授. 工学博士. 主に, 進化的計算法, コンピュータビジョン, 概念 処理などの研究に従事. 言語処理学会, 人工知能学会, 情報処理学会, 電子 情報通信学会, システム制御情報学会, 精密工学会各会員.

河岡 司: 1966 年大阪大学工学部通信工学科卒業. 1968 年同大学院修士課程 修了. 同年, 日本電信電話公社入社, 情報通信網研究所知識処理研究部長, NTT コミュニケーション科学研究所所長を経て, 現在同志社大学工学部教 授. 工学博士. 主にコンピュータネットワーク, 知識情報処理の研究に従事. 言語処理学会, 人工知能学会, 情報処理学会, 電子情報通信学会, $\operatorname{IEEE}(\mathrm{CS})$ 各会員.

(2005 年 8 月 1 日 受付)

(2005 年 9 月 5 日 再受付)

$(2005$ 年 9 月 15 日 採録) 